\title{
Mitogen stimulation of peripheral blood lymphocytes of duodenal ulcer patients during treatment with cimetidine or ranitidine
}

\author{
N R PEDEN, A J ROBERTSON, E J S BOYD, R A BROWN, J H GIBBS, \\ R C POTTS, K G WORMSLEY, and J SWANSON BECK* \\ From the Departments of Pharmacology and Therapeutics, of Pathology, and of Mathematics, Ninewells \\ Hospital and Medical School, The University, Dundee
}

SUMmARY During a double-blind randomised clinical trial of cimetidine and ranitidine in the management of duodenal ulcer, the response of patients' peripheral blood lymphocytes to optimal mitogenic stimulation in vitro has been measured. Treatment with cimetidine, but not ranitidine, was associated with a significant increase in the proportion of peripheral blood lymphocytes responding to this optimal mitogenic stimulation. We conclude that these effects of cimetidine may not be mediated at classical histamine $\mathrm{H}_{2}$-receptors.

Exogenous histamine in non-toxic concentrations suppresses proliferation in vitro of mitogenstimulated lymphocytes. ${ }^{1}$ It has been proposed that the suppressive activity is mediated through $\mathrm{H}_{2}$ receptors, as it is inhibited by $\mathrm{H}_{2}$-antagonists ${ }^{2}$ and potentiated by $\mathrm{H}_{2}$-agonists. ${ }^{3}$ Histamine appears to stimulate T-cells to release a suppressive factor ${ }^{4}$ but a small number of adherent cells are necessary. ${ }^{5}$ Studies with human lymphocytes have shown that concanavalin A (Con A) activates suppressor cells by provoking histamine release and that this effect is blocked by cimetidine (an $\mathrm{H}_{2}$-antagonist): ${ }^{6}$ moreover, cimetidine augments the proliferative response of human lymphocytes to both mitogens and antigens. ${ }^{7}$ Ranitidine behaves as a specific $\mathrm{H}_{2}$-antagonist to conventional models (such as inhibition of gastric secretion $)^{8}$ with a molar potency four to eight times greater than cimetidine in $\operatorname{man}^{9-11}$ but it lacks the imidazole nucleus common to histamine and cimetidine (Figure).

This study was undertaken to determine whether cimetidine and ranitidine, when used in the treatment of patients with clinically active duodenal ulcer, would significantly alter the function of peripheral blood lymphocytes in these patients. The model of lymphocyte function chosen for study was the in-vitro response to mitogenic stimulation with phytohaemagglutinin Con $\mathrm{A}$, and pokeweed mitogen.

* Address for correspondence: Professor J Swanson Beck, Department of Pathology, Ninewells Hospital and Medical School, PO Box 120, Dundee, DD1 9SY.

Received for publication 19 October 1981

\section{Methods}

\section{PATIENTS}

Patients gave informed consent to the study which had the approval of the Dundee District Ethical Committee. The 33 patients studied had endo-
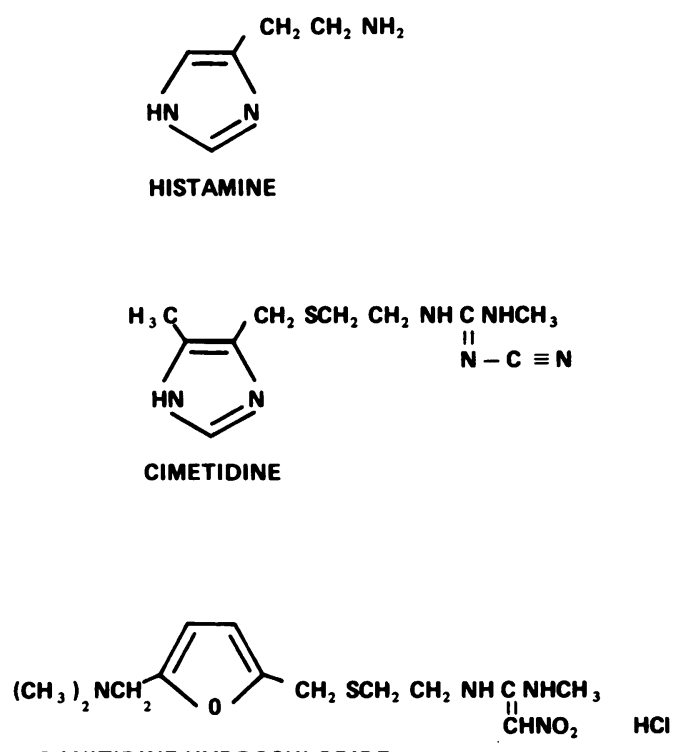

RANITIDINE HYDROCHLORIDE

Figure Chemical structures of histamine, cimetidine, and ranitidine hydrochloride 
scopically proven duodenal ulcers and were participating in a double-blind randomised clinical trial which has been reported in detail elsewhere. ${ }^{12}$ After randomisation patients were treated with cimetidine $800 \mathrm{mg} /$ day or ranitidine $320 \mathrm{mg} /$ day, the dosing schedule being one tablet with breakfast and lunch and two before retiring. The patients in the two treatment groups were comparable (Table 1). After 28 days of treatment, eight of 18 patients given cimetidine and 11 of 15 given ranitidine had achieved complete healing of their ulcers, while 10 of 18 and 11 of 15 respectively were free of symptoms.

\section{INVESTIGATIONS}

Where possible, each patients was studied on three occasions - namely, before treatment, after 14 days of treatment (one to two hours after dosing) and after 28 days of treatment (14-18 hours after the last tablet had been taken). Certain blood samples were unsuitable for culture - namely, in the cimetidine series, those from three patients at 14 days and from four patients at 28 days and in the ranitidine series, one each at the pretreatment, 14 days' and 28 days' sampling times. No patient was included in the series if more than one sample were missed.

Blood was withdrawn from the patient who had been fasted overnight and after at least 15 minutes' rest so that peripheral blood lymphocytes in the sample would be representative of the basal state. ${ }^{13}$ Blood for mitogen stimulation tests was taken into heparinised tubes while blood for counting the total numbers of lymphocytes was taken into sequestrene tubes.

\section{LYMPHOCYTE STIMULATION TESTS}

The laboratory workers in the group did not know which drugs individual patients were receiving nor the clinical progress when the tests were being performed. Mononuclear cells were isolated from heparinised blood samples by Ficoll/Hypaque density gradient centrifugation. ${ }^{14}$ Lymphocytes were the predominant cell type in the specimens used in this investigation (>90\%); as monocytes are necessary for the response to mitogen stimulation ${ }^{15}$ no attempt was made to purify the lymphocyte suspension by removal of the phagocytic cells lest this procedure introduced an uncontrollable variable between samples from different patients. The harvested cells were washed in tissue culture fluid before testing.

The method used for study of lymphocyte response to mitogen stimulation has been described in detail previously. ${ }^{16}$ Briefly, the incubation mixture in each round-bottomed well of a microtitre plate (Sterilin Ltd, Teddington, England) contained (1) $100 \mu$ l lymphocyte-rich suspension $\left(2 \times 10^{5}\right.$ cells $)$, (2) $50 \mu \mathrm{l}$ mitogen dissolved in culture fluid, and (3) $20 \mu \mathrm{l}$ autologous plasma. The plates were sealed with adhesive tape (Flow Laboratories, Irvine, Scotland) and incubated at $37^{\circ} \mathrm{C}$ for $22-24$ hours. The standard tissue culture fluid was medium TC199 (Gibco-Biocult, Paisley, Scotland) supplemented with L-glutamine $(200 \mathrm{mM})$, penicillin $(200 \mathrm{IU} / \mathrm{ml})$ and streptomycin $(100 \mu \mathrm{g} / \mathrm{ml})$. The mitogens (used at optimal concentrations) were phytohaemagglutinin (Wellcome Reagents Ltd, Beckenham, England) at 5.0 $\mu \mathrm{l} \mathrm{HA15/ml} \mathrm{TC199,} \mathrm{Con} \mathrm{A} \mathrm{(Sigma,}$ St Louis, USA) at $100 \mu \mathrm{l} / \mathrm{ml}$, and pokeweed mitogen (Gibco-Biocult) at $20 \mu \mathrm{l} / \mathrm{ml}$. The exact duration of culture was noted at the time of harvesting when the cells were disaggregated and dispersed by repeated pasteur pipette mixing. The relative numbers of lymphocytes and phagocytic cells in the cells harvested from the control wells were determined by volume spectroscopy ${ }^{17}$ - with the methods currently used in this laboratory, $90-95 \%$ of the seeded lymphocytes are harvested by pipette mixing, but few of the monocytes are recovered, presumably because they adhere to the walls of the plastic microtitre plates. ${ }^{18}$ The volume distribution of the control and stimulated cultures was measured with an electronic particle counter and a multichannel analyser (Fn and C1000, Coulter Electronics, Harpenden, England). Because of cultural failures, no results are available for Con A stimulation on one sample from a cimetidine patient and from four samples from ranitidine patients. These profiles were analysed by computer to determine the percentage of the cells responding to stimulation and their averaged growth rate $(a+b v)$, where $v$ is the volume of the cell and $a$ and $b$ are constants, named the basal and incremental growth rates respectively. ${ }^{18} 19$

Table 1 Details of patients included in study

\begin{tabular}{|c|c|c|c|c|c|c|}
\hline Treatment & Number & Males & Females & $\begin{array}{l}\text { Mean age } \\
(y r)\end{array}$ & $\begin{array}{l}\text { Mean duration } \\
\text { of ulcer history } \\
(y r)\end{array}$ & $\begin{array}{l}\text { Cigarette } \\
\text { smokers }\end{array}$ \\
\hline Cimetidine & 18 & 13 & 5 & $43 \cdot 2$ & $8 \cdot 9$ & 14 \\
\hline Ranitidine & 15 & 9 & 6 & $45 \cdot 4$ & $9 \cdot 8$ & 11 \\
\hline
\end{tabular}




\section{PERIPHERAL BLOOD LYMPHOCYTE COUNTS}

The white blood cell count was measured in the sequestrene blood sample with a Coulter (Model S) counter and the differential count was performed microscopically in Leishman-stained blood films.

\section{STATISTICAL METHODS}

The findings of the three sampling times were subjected to a two-way analysis of variance using the Generalised Linear Interactive Modelling Package produced by the Royal Statistical Society. ${ }^{20}$ The Tukey one-degree of freedom test ${ }^{21}$ was used to assess the validity of the assumption of additivity. An additional series of non-parametric analyses using the Friedman rank test ${ }^{22}$ was performed to assess the pattern of changes with time. This test was used as a back-up, as it is not sensitive to outliers. The Tukey median polish technique ${ }^{23}$ was used to provide robust estimates of the change in percentage of responsive lymphocytes with time.

\section{Results}

\section{PERIPHERAL BLOOD LYMPHOCYTES DURING TREATMENT WITH CIMETIDINE}

The findings on numbers of lymphocytes circulating in the peripheral blood are summarised in Table 2 . The mean white blood cell count fell during the period of study. For individual patients the mean reduction from the pretreatment level was $1 \cdot 1 \pm 0.4$ (SD) $\times 10^{9} / 1$ at two weeks and $1.5 \pm 0.4 \times 10^{9} / 1$ at four weeks: these differences were statistically significant $(p<0.01)$. There were no consistent changes in the percentage of lymphocytes in the differential count: for individual patients the mean change was a fall of $0 \cdot 1 \pm 2 \cdot 1 \%$ at two weeks and a rise of $1 \cdot 5 \pm 2 \cdot 3 \%$ at four weeks and these differences were not statistically significant. The calculated absolute lymphocyte count fell during the period of study, but the mean fall from the pretreatment level for
Table 2 Summary of haematological findings in duodenal ulcer patients treated with cimetidine or ranitidine (data presented as mean $\pm S D$ )

\begin{tabular}{|c|c|c|c|c|}
\hline Drug & $\begin{array}{l}\text { Duration of } \\
\text { treatment } \\
\text { (wk) }\end{array}$ & $\begin{array}{l}f \\
W B C \\
\left(\times 10^{9} / l\right)\end{array}$ & $\begin{array}{l}\% \\
\text { Lymphocytes } \\
\text { in differential } \\
\text { count }\end{array}$ & $\begin{array}{l}\text { Absolute } \\
\text { lymphocyte } \\
\text { count } \\
\left(\times 10^{9} / l\right)\end{array}$ \\
\hline Cimetidine & $\begin{array}{l}0 \\
2 \\
4\end{array}$ & $\begin{array}{l}8 \cdot 1 \pm 2 \cdot 1 \\
7 \cdot 1 \pm 1 \cdot 8 \\
6 \cdot 5 \pm 1 \cdot 6\end{array}$ & $\begin{array}{l}32 \cdot 5 \pm 7 \cdot 4 \\
31 \cdot 9 \pm 9 \cdot 1 \\
33 \cdot 8 \pm 8 \cdot 0\end{array}$ & $\begin{array}{l}2 \cdot 5 \pm 0 \cdot 7 \\
2 \cdot 2 \pm 0 \cdot 8 \\
2 \cdot 2 \pm 0 \cdot 7\end{array}$ \\
\hline Ranitidine & $\begin{array}{l}0 \\
2 \\
4\end{array}$ & $\begin{array}{l}7 \cdot 4 \pm 1 \cdot 2 \\
7 \cdot 1 \pm 1 \cdot 6 \\
6 \cdot 7 \pm 2 \cdot 0\end{array}$ & $\begin{array}{l}29 \cdot 8 \pm 5 \cdot 9 \\
30 \cdot 4 \pm 6 \cdot 7 \\
29 \cdot 2 \pm 6 \cdot 0\end{array}$ & $\begin{array}{l}2 \cdot 2 \pm 0 \cdot 4 \\
2 \cdot 1 \pm 0 \cdot 6 \\
1 \cdot 9 \pm 0 \cdot 6\end{array}$ \\
\hline
\end{tabular}

individual patients was not statistically significant $(0.42 \pm 0.49 \%$ at two weeks and $0.4 \pm 0.7 \%$ at four weeks).

The findings on analysis of variance of results of lymphocyte stimulation tests are summarised in Table 3.

All patients responded in a comparable manner. None of the Tukey one-degree of freedom tests for non-additivity was significant. After treatment with cimetidine for two weeks there was a large and significant increase in the proportion of the peripheral blood lymphocytes that had entered $\mathrm{G}_{1}$-phase growth in response to stimulation with each of the three mitogens. After four weeks' treatment, the response to phytohaemagglutinin was still markedly and significantly increased, that to Con A was increased to a lesser but still significant $(p<0.05)$ extent, but that to pokeweed mitogen was not significantly changed from the pretreatment level. The validity of these conclusions was confirmed, in pattern, by the Friedman rank tests and, in extent, by the Tukey median polish estimates. The changes in incremental growth rates were not statistically significant. The effects were unrelated to the sex of the patient or to the

Table 3 Results of analysis of variance of changes with time in responses of lymphocytes from patients with duodenal ulcer to mitogen stimulation during course of treatment

\begin{tabular}{|c|c|c|c|c|c|c|c|}
\hline \multirow{3}{*}{$\begin{array}{l}\text { Drug } \\
\text { treatment }\end{array}$} & \multirow[b]{3}{*}{ Mitogen } & \multirow{3}{*}{$\begin{array}{l}\text { No. of } \\
\text { patients } \\
\text { studied }\end{array}$} & \multicolumn{5}{|c|}{ Changes in percentage of cells responding to mitogen stimulation } \\
\hline & & & \multirow{2}{*}{$\begin{array}{l}\text { Variance } \\
\text { ratio }\end{array}$} & \multirow{2}{*}{$\begin{array}{l}\text { Degrees of } \\
\text { freedom }\end{array}$} & \multirow[b]{2}{*}{ Probability } & \multicolumn{2}{|c|}{$\begin{array}{l}\text { Mean increase in percentage of } \\
\text { lymphocytes responding } \pm S D \\
\text { after treatment for }\end{array}$} \\
\hline & & & & & & 14 days & 28 days \\
\hline \multirow[t]{3}{*}{ Cimetidine } & PHA & 16 & $4 \cdot 83$ & $2: 24$ & $<0.025$ & $12 \cdot 0 \pm 4 \cdot 6$ & $12 \cdot 3 \pm 4 \cdot 6$ \\
\hline & Con A & 17 & $5 \cdot 88$ & $2: 26$ & $<0.01$ & $13 \cdot 8 \pm 4 \cdot 0$ & $7 \cdot 6 \pm 4 \cdot 4$ \\
\hline & PWM & 18 & $5 \cdot 93$ & $2: 27$ & $<0.01$ & $15 \cdot 6 \pm 4 \cdot 6$ & $3 \cdot 7 \pm 4 \cdot 7$ (N.S.) \\
\hline \multirow[t]{3}{*}{ Ranitidine } & PHA & 15 & 0.81 & $2: 21$ & NS & $-7 \cdot 1 \pm 5 \cdot 7$ & $-5 \cdot 1 \pm 5 \cdot 6$ \\
\hline & Con $\mathbf{A}$ & 14 & 0.07 & $2: 22$ & NS & $2 \cdot 2 \pm 6 \cdot 1$ & $1 \cdot 2 \pm 6 \cdot 1$ \\
\hline & PWM & 15 & 0.58 & $2: 25$ & NS & $-3 \cdot 8 \pm 4 \cdot 9$ & $-5 \cdot 1 \pm 5 \cdot 0$ \\
\hline
\end{tabular}


achievement of ulcer healing during the period of study.

\section{PERIPHERAL BLOOD LYMPHOCYTES DURING} TREATMENT WITH RANITIDINE

The findings on numbers of lymphocytes circulating in the peripheral blood are summarised in Table 2 . Although the mean white blood cell count fell during the period of study, the mean decrease from pretreatment levels was small $\left(0 \cdot 5 \pm 0 \cdot 3 \times 10^{9} / 1\right.$ at two weeks and $0.7 \pm 0.3 \times 10^{9} / 1$ at four weeks) and did not achieve statistical significance. There were no consistent changes in the percentages of lymphocytes in the differential count: for individual patients, the mean rise at two weeks was $0 \cdot 8 \pm 1 \cdot 8 \%$. The calculated absolute lymphocyte count fell during the period of study, but the changes for individual patients were not statistically significant (rise of $0.15 \pm 0.72 \times 10^{9} / 1$ at two weeks and fall of $0 \cdot 3 \pm 0.49 \times 10^{9} / 1$ at four weeks).

The findings in the mitogen stimulation tests on lymphocytes for ranitidine-treated patients are summarised in Table 3 . These are in complete contrast with the effects of cimetidine, as with ranitidine there were no significant differences either in percentage of cells responding or in their incremental growth rate with any of the three mitogens. The Friedman rank test results and the Tukey median polish estimates confirmed the twoway analysis of variance.

\section{Discussion}

We have shown an increased response to in vitro mitogen-stimulation in peripheral blood lymphocytes from duodenal ulcer patients during treatment with cimetidine. A greater proportion of cells enter $\mathrm{G}_{1}$-phase and the absence of change in incremental growth rate implies that the kinetics of recruitment into growth are unchanged. ${ }^{24}$ It is not possible to deduce from our studies whether cimetidine, when administered orally, influences the lymphocyte directly (as would be implied by increased mitogen responses of normal lymphocytes seen after addition of the drug to the culture medium $)^{7}$ or whether it causes an in vivo redistribution between the pools of lymphocytes in the peripheral blood and the lymphoid organs or other solid tissues: the absence of any major changes in the absolute numbers of circulating lymphocytes argues against the latter mechanism.

The different response to the mitogens in the 14 and 28 day samples is of interest, as blood samples drawn at 14 days would be expected to contain significant quantities of active drug, while those drawn at 28 days (14-16 hours after the last dose) would not be expected to contain detectable quantities of either drug. ${ }^{25} 26$ Our findings, therefore, suggest that some, at least, of the immunological effects of cimetidine are rapidly reversed on stopping treatment.

Previous studies of human lymphocyte function in relationship to cimetidine have given contradictory results. While the in vitro studies of Gifford et $\mathrm{al}^{7}$ produced findings broadly in accord with our own, Festen $e t a l^{27}$ were unable to show any effect of cimetidine treatment on lymphocyte function in nine patients with duodenal ulcer. Jorizzo et $a l^{28}$ found that cimetidine treatment increased the in vitro lymphocyte response to candida, but not to mitogens, in patients with chronic mucocutaneous candidiasis. Cimetidine treatment appears to correct skin anergy in $\operatorname{man}^{29-31}$ and there is anecdotal evidence that it may be immunostimulant in metastatic cancer ${ }^{32}$ and in potentiating renal allograft rejection, ${ }^{33}$ although the latter conclusion is disputed. ${ }^{35-37}$

In contrast with the marked and consistent effects of cimetidine we were unable to demonstrate any effect of treatment with ranitidine or lymphocyte function, despite using doses which produce profound inhibition of gastric secretion, ${ }^{38}$ and produce ulcer healing. Ranitidine and cimetidine, used in doses which exert profound pharmacological effects at the classical $\mathrm{H}_{2}$-receptors, ${ }^{39}$ nevertheless had very different effects on lymphocyte function, indicating that the effects of cimetidine on lymphocyte function might not be mediated by classical $\mathrm{H}_{2}$-receptors. Support for this hypothesis is provided by studies of Vickers et a ${ }^{40}$ who found that nordimaprit (an analogue of dimaprit without intrinsic $\mathrm{H}_{2}$-agonist activity) had similar effects on histamine and dimaprit (a potent $\mathrm{H}_{2}$-agonist) on lymphocyte function. Eyre and Chand ${ }^{41}$ have reviewed the evidence for two subclasses of $\mathrm{H}_{2}$ receptor in other systems.

Other situations have been reported in which cimetidine and ranitidine have different effects. Thus cimetidine, but not ranitidine, stimulates prolactin secretion on bolus injection, ${ }^{42}$ increases serum testosterone levels, ${ }^{43}$ and inhibits hepatic microsomal drug metabolism. ${ }^{44}$ It remains to be seen whether any of these effects, which are not thought to be mediated at $\mathrm{H}_{2}$-receptors, are related to the effects of cimetidine on lymphocyte function. It appears that the imidazole nucleus of cimetidine provides the molecular basis for functional activity in these different systems and that the change from imidazole to the substituted furan nucleus in ranitidine abolishes these effects while retaining the antisecretory effects. 
In conclusion, we have shown that treatment with cimetidine in vivo augments the response of lymphocytes from patients with duodenal ulcer to in vitro mitogenic stimulation, while treatment with ranitidine does not. These results suggest that the effect of cimetidine on lymphocytes is not mediated at classical histamine $\mathrm{H}_{2}$-receptors.

This investigation was supported by a grant from the Scottish Home and Health Department (K/MRS/50/ $\mathrm{C281}$ ). We are grateful to Mrs $\mathrm{R}$ Mitchell for valuable secretarial assistance.

\section{References}

1 Wang SR, Zweiman B. Histamine suppression of human lymphocyte responses to mitogens. Cell Immunol 1978; 36: 28-36.

2 Rocklin RE. Histamine induced suppressor factor (HSF): effect on migration inhibitory factor (MIF) production and proliferation. J Immunol 1977; 118: 1734-8.

3 Rocklin RE, Haberek-Davidson A. Histamine activates suppressor cells in vitro using a coculture technique. J Clin Immunol 1981; 1: 73-9.

4 Rocklin RE, Greineder DK, Melmon KL. Histamineinduced suppressor factor (HSF): further studies on the nature of the stimulus and the cell which produces it. Cell Immunol 1979; 44: 404-15.

5 Hébert J, Beaudoin R, Aubin M, Fontaine M. The regulatory effect of histamine on the immune response: characterisation of the cells involved. Cell Immunol 1980; 54: 49-57.

6 Osband M, Gallison D, Miller B, Aganeval RP, McCaffrey RP. Concanavalin A activation of suppressor cells is mediated by the release of histamine and is blocked by cimetidine. Clin Res 1980; 28: 356A.

7 Gifford RRM, Hatfield SM, Schmidtke JR. Cimetidine-induced augmentation of human lymphocyte blastogenesis by mitogen, bacterial antigen, and alloantigen. Transplantation 1980; 29: 143-8.

8 Bradshaw J, Brittain RT, Clitherow JW et al. Ranitidine (AH 19065); a new potent, selective histamine $\mathrm{H}_{2}$-receptor antagonist. (Abstract). $\mathrm{Br} J$ Pharmacol 1979; 66: 464P.

9 Konturek SJ, Obtulowicz W, Kwiecien N, Sito E, Mikos E, Oleksy J. Comparison of ranitidine and cimetidine in the inhibition of histamine, sham-feeding, and meal-induced gastric secretion in duodenal ulcer patients. Gut 1980; 21: 181-6.

10 Peden NR, Richards DA, Saunders JHB, Wormsley KG. Pharmacologically-effective plasma concentrations of ranitidine. Lancet 1979; 2: 199-200.

11 Walt RP, Male P-J, Rawlings J, Hunt RH, MiltonThompson GJ, Misiewicz JJ. Comparison of the effects of ranitidine, cimetidine and placebo on the $24 \mathrm{hr}$ intragastric acidity, and nocturnal acid secretion in patients with duodenal ulcer. Gut 1981; 22: 49-54.

12 Peden NR, Boyd EJS, Saunders JHB, Wormsley KG. Ranitidine in the treatment of duodenal ulcer. Scand $J$ Gastroenterol 1981; 16: 325-9.

13 Robertson AJ, Ramesar KCRB, Potts RC et al. The effect of strenuous physical exercise on circulating blood lymphocytes and serum cortisol levels. J Clin Lab Immunol 1981; 5: 53-7.

14 Böyum A. Isolation of mononuclear cells and granulocytes from human blood. Isolation of mononuclear cells by one centrifugation and of granulocytes by combining centrifugation and sedimentation at $1 \mathrm{~g}$. Scand J Clin Lab Invest 1968; 21, suppl 97: 77-89.

15 Potter MR, Moore M. The effect of adherent and phagocytic cells on human lymphocyte PHA responsiveness. Clin Exp Immunol 1977; 27: 159-64.

16 Gibbs JH, Brown RA, Robertson AJ, Potts RC, Beck JS. A new method of testing for mitogen-induced lymphocyte stimulation: measurement of the percentage of growing cells and of some aspects of their cell kinetics with an electronic particle counter. J Immunol Methods 1979; 25: 147-58.

17 Potts RC, Gibbs JH, Robertson AJ, Brown RA, Beck JS. A simple method for determining the extent of cellular contamination in peripheral blood lymphocyte preparations. J Immunol Methods 1980; 35: 177-87.

18 Potts RC, Sherif MM, Robertson AJ, Gibbs JH, Brown RA, Beck JS. Serum inhibitory factor in lepromatous leprosy: its effect on the pre-S-phase cell cycle kinetics of mitogen-stimulated normal human lymphocytes. Scand J Immunol 1981; 14: 269-80.

19 Brown RA, McWalter R, Slidders W, Gibbs J, Beck JS. Measurement by Quantimet 720 of the proportion of actively growing cells in tissue cultures of human lymphocytes. J Microsc 1979; 115: 51-63.

20 Baker RJ, Nelder JA. Generalised linear interactive modelling. Release 3. London: Royal Statistical Society, 1978.

21 McCullagh P. A comparison of transformations of chimpanzee learning data. Glim Newsletter 1980; June 14-18.

22 Conover WJ. Practical nonparametric statistics, 2nd ed. New York: John Wiley, 1980: 299-302.

23 Tukey JW. Exploratory data analysis. Reading, Mass: Addison-Wesley Publishing Co., 1977: 363-85.

24 Brown RA, Gibbs JH, Robertson AJ, Potts RC, Beck JS. Development of asynchrony in growth of normal human lymphocytes during first day of culture after PHA stimulation. Exp Cell Res 1980; 126: 87-97.

25 Woodings EP, Dixon GT, Harrison C, Carey P, Richards DA. Ranitidine - a new $\mathrm{H}_{2}$-receptor antagonist. Gut 1980; 21: 187-91.

26 Bodemar G, Norlander B, Fransson L, Walan A. The absorption of cimetidine before and during maintenance treatment with cimetidine and the influence of a meal on the absorption of cimetidine studies in patients with peptic ulcer disease. $\mathrm{Br} J$ Clin Pharmacol 1979; 7: 23-31.

27 Festen MPM, Berden JHM, de Pauw BE. Immunological studies in patients treated with cimetidine and the influence of cimetidine on graft survival in mice. In: Torsoli A, Luchelli PE, Brimblecombe RA, eds. 
$H_{2}$-antagonists. Amsterdam: Excerpta Medica, 1980: 327.

28 Jorizzo JL, Sams WM, Jegasothy BV, Olansky AJ. Cimetidine as an immuno-modulator: chronic mucocutaneous candidiasis as a model. Ann Intern Med 1980; 92: 192-5.

29 Daman LA, Rosenberg EW. Acquired tolerance to dinitrochlorobenzene reversed by cimetidine. Lancet 1977; 2: 1087.

30 Breuilland F, Szapiro E. Cimetidine in acquired tolerance to dinitrochlorobenzene. Lancet 1978; 1: 726.

31 Bicks RO, Rosenberg EW. Reversal of anergy in Crohn's disease by cimetidine. Lancet 1980; 1: 552-3.

32 Armitage JO, Sidner RD. Antitumour effect of cimetidine? Lancet 1979; 1: 882-3.

33 Primack WA. Cimetidine and renal allograft rejection. Lancet 1978; 1: 824-5.

34 Zammit M, Toledo-Pereyra LH. Increased rejection after cimetidine treatment in kidney transplants. Transplantation 1979; 27: 358-9.

35 Docherty CC, McGeown MG. Cimetidine and renal allograft rejection. Lancet 1978; 1: 1048.

36 Rudge CJ, Jones RH, Bewick M, Weston MJ, Parsons $\mathrm{V}$. Cimetidine and renal allograft rejection. Lancet 1978; 1: 1154.

37 Chapentier B, Fries D. Cimetidine and renal allograft rejection. Lancet 1978; 1: 1265.
38 Peden NR, Saunders JHB, Wormsley KG. Inhibition of pentagastrin - stimulated and nocturnal gastric secretion by ranitidine. Lancet 1979; 1: 690-2.

39 Black JW, Duncan WAM, Durant GJ, Ganellin CR, Parsons EM. Definition and antagonism of histamine $\mathrm{H}_{2}$-receptors. Nature (Lond) 1972; 236: 385-90.

40 Vickers MR, Arlington SA, Jones C, Martin D, Melvin MA. The role of histamine in immune responses. In: Torsoli A, Luchelli PE, Brimblecombe RA, eds. $\mathrm{H}_{2}$-antagonists. Amsterdam: Excerpta Medica, 1980: 311.

41 Eyre P, Chang N. Preliminary evidence for two subclasses of histamine $\mathrm{H}_{2}$-receptors. Agents and Actions 1979; 9/1: 1-3.

42 Nelis BF, Van der Meene JGC. Comparative effect of cimetidine and ranitidine on prolactin secretion. Postgrad Med J 1980; 56: 478-80.

43 Peden NR, Boyd EJS, Browning MCK, Saunders JHB, Wormsley KG. Effects of treatment with two histamine $\mathrm{H}_{2}$-receptor antagonists on basal levels of luteinising hormone, follicle stimulating hormone, prolactin, testerone and oestradiol-17- $\beta$ in men with duodenal ulcer. Acta Endocrinol (Kbh) 1981; 96: 564-8.

44 Henry DA, MacDonald IA, Kitchingham G, Bell GD, Langman MJS. Cimetidine and ranitidine: comparison of effects on hepatic drug metabolism. Br Med J 1980; 281: 775-7. 